6

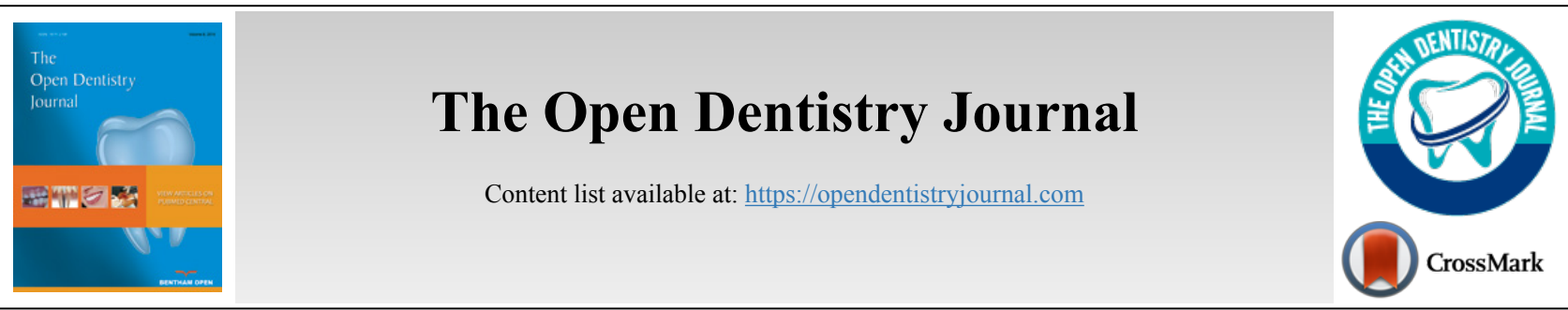

RESEARCH ARTICLE

\title{
A New Tooth Processing Apparatus Allowing to Obtain Dentin Grafts for Bone Augmentation: The Tooth Transformer
}

\author{
Elio Minetti ${ }^{1}$, Marco Berardini ${ }^{2, *}$ and Paolo Trisi ${ }^{2}$ \\ ${ }^{1}$ Private Practice, Milano, Italy \\ ${ }^{2}$ Biomaterial Clinical and Histological Research Association; Private Practice, Pescara, Italy
}

\begin{abstract}
:
Introduction:

Human dentin matrix could be considered an excellent alternative to autologous or heterologous bone graft. Autologous tooth graft has been proposed since 1967 when the osteoinduction properties of autogenous demineralized dentin matrix were discovered.

\section{Methods:}

The preparation technique to transform autologous teeth in suitable grafting material still represents the fundamental step of the whole procedure.

Aim:

The aim of the present study was to test an innovative medical device that could obtain tooth graft materials starting from the whole tooth of the patient. 15 consecutive cases of tooth grafting procedures were performed with a mean follow up period of 18 months.

Results:

In all cases, after 6 months of healing, the defects were almost completely filled by newly formed hard tissue. The new tissue was examined after 6 months, both from a radiological point of view by CBCT scans and from a clinical observation. It showed a compactness similar to the mediumdensity bone. No signs of inflammations were observed. No infective complications were recorded during the post-operative healing. No graft particles or grains were visible in the regenerated bone structure that appeared homogeneous and uniform.

\section{Discussion:}

The results of the present study showed favorable bony healing in guided regenerative surgery procedures using autologous tooth graft. Future studies with long follow up period are needed in order to better evaluate the potential of demineralized dentin autografts.
\end{abstract}

Keywords: Bone regeneration, Tooth graft, Dentin matrix, Oral implantology, Dentin graft, CBCT.

\section{INTRODUCTION}

Grafting materials are widely used for pre and peri-implant bone augmentation procedures from more than 35 years [1, 2]. The most commonly used graft materials are from animal origin, synthetic or human. In these cases, bone regeneration stimulation derives from the host organism and never from the donor, slowing or decreasing the regenerative potential. Autogenous bone graft is considered the gold standard for the

* Address correspondence to this author at the Biomaterial Clinical and Histological Research Association; Private Practice, Via Galilei 8, 65122 Pescara, Italy; Tel: +390857933050; Fax: +390857933050;

E-mail: dottmarcoberardini@gmail.com repair of alveolar bone defects, but it is associated with donor complications and morbidity and also suffers from a limited supply.

Permanent teeth graft has been proposed since 1967, when Yeomans and Urist [3] and Bang and Urist [4] demonstrated osteoinduction properties of autogenous demineralized dentin matrix; some years later, Kawai and Urist partially purified bone morphogenetic proteins of bovine dentin matrix [5].

The idea to use autogenous tooth as bone substitute in grafting procedure started from similar chemical composition between bone and dentin. Both of them consist, in fact, of $18 \%$ collagen, $2 \%$ proteins, $70 \%$ inorganic portion (hydroxyapatite), 
and $10 \%$ of fluids. Both tooth and alveolar bone are derived from neural crest cells and are made up of the same type I collagen.

In 1991, Bessho et al. [6], demonstrated the presence of Bone Morphogenetic Proteins (BMPs) from human dentin matrix. Therefore, both bone and dentin matrix is a repository for growth factors, such as Bone Morphogenetic Proteins (BMPs) and basic fibroblast growth factor. It was also reported that the demineralized human dentin matrix was able to induce bone and cartilage formation in mouse muscles with the concomitant presence of bone-forming cells (osteoblasts) [7]. The consistent number of recent studies $[8,9]$ existing in this topic testifies the scientific increasing interest about this possibility for grafting procedures.

The demineralized dentin matrix may represent an efficient reserve of BMPs because highly soluble BMPs do not exert osteoinductive effects when used alone. Bioactive Growth Factors (GFs), such as Transforming Growth Factor-B (TGFB) and bone morphogenic proteins (BMPs), which are known to be present in and released from dentin, are involved in bone repairing processes [10].

The preparation technique to transform autologous teeth in suitable grafting material represents the key step of the whole procedure. It is fundamental to preserve the organic autologous components to stimulate bone progenitor cells, remove any contaminants to avoid inflammatory or infective reactions, and prepare the inorganic part to be easily colonized by osteoblasts. The demineralization process is required for freeing the various growth factors and proteins, since the release of the growth factors is sometimes blocked by the presence of hydroxyapatite crystals [11]. Through the reduction of the mineral phase, demineralization supports the release of such growth factors from the tooth matrix [12].

At present, demineralized autogenous dentin is available in two forms, granules and block [13]. Some authors [14] theorized that the geometry and granules size assume a fundamental importance in terms of bone regeneration properties. Recently, Koga et al. [15], recommended the use of $1000 \mu \mathrm{m}$ particles and a partial demineralization with $2 \%$ $\mathrm{HNO}_{3}$.

There are some devices, on the market, that allow to grind the tooth of the patient to produce dentin granules. These devices need a manual control by the clinicians in grinding process without any control in particles size. Furthermore, also the chemical treatment to obtain tooth decontamination and demineralization is entrusted to the operator's manual skills [16].

Recently, an innovative medical device (TT TOOTH TRANSFORMER SRL, Via Washington, 59 - Milan, Italy) to obtain suitable tooth graft materials starting from the whole tooth of the patient was introduced to the market. All grinding and demineralizing processes are completely automated without any human possibility of error. According to the manufacturer, this new device represents an advanced system in the area of tissue engineering that can process and transform extracted tooth into useful bone graft material in a short time. The autogenous genetic content guarantees absolute com- patibility with the recipient site and most importantly, the content of BMP-2 (Bone Morphogenic Proteins that stimulate bone growth), found by some authors in a previously published in vitro investigation [17], could guarantees high osteoinduction.

This autologous tooth graft should be able to stimulate adhesion, proliferation and cellular differentiation and to promote the bone regeneration. The high wettability allows the ease of handling. The tooth like a bone, is made of collagen type 1 and minerals of Hydroxyapatite (HA). The tooth transformer reduces the crystallinity of the HA, eliminates the bacteria and transforms the dentin into an autologous graft material. In vitro studies demonstrated the presence and the freeing of BMP-2 from tooth and the elevated biocompatibility of the dentin after treatment [18].

The present paper aims to present clinical and histological outcomes of 11 consecutive case of socket preservation and 4 cases of sinus lift using innovative autologous tooth grafting procedure.

\section{MATERIALS AND METHODS}

The present case series included 15 patients $(7$ male and 8 female), age ranged between 22 to 64 years old. All patients were in good health conditions and were nonsmokers. In 11 cases, the patients needed guided bone regeneration procedures while in other 4 cases, patients asked for maxillary sinus elevation. An informed and written consent to the surgical treatment was obtained from each subject. The approval of the ethical committee was not needed because it is a case series analysis without any experimental material or procedures (the device is present in the market). The patients were advised that the bone regeneration procedures would be made using autologous tooth as regenerative material and each patient declared to understand the benefits of using an autologous bone regeneration material.

In each case, the patient underwent 3D radiological analysis (Fig. 1) before proceeding to tooth extraction and/or regeneration procedures. Three to four days before surgery, patients were prepared with an oral hygiene session and received a reinforcing oral hygiene instruction to have an appropriate cleanliness by means of electric-toothbrush. Twenty-four hours before surgery, antibiotic prophylaxis was started (amoxicillin $1 \mathrm{~g}$ twice a day for 6 days).

In cases in which also tooth extractions were planned ( 9 patients out 11), patients underwent hopeless tooth extraction some minutes before starting bone regenerative procedures while in the remaining two cases deciduous or wisdom teeth, conserved by the patient over the years, were used.

In all cases, extracted teeth were carefully cleaned and any foreign materials were removed including calculus, restorations and endodontic filling materials before its insertion in the device (Fig. 2). Cementum was not removed.

In particular, the tooth of the patient was treated for:

- Cleaning of residual calculus using piezoelectric instrument; 
- Cleaning the root surface using diamond burs;

- Removing any filling materials (guttapercha, composite, etc.)

- Finally, it was cut in small pieces to facilitate the milling process.

Subsequently, the tooth was placed inside the mill. A small box containing disposable liquids was inserted in the device in its correct position (indicated by arrows). According to the manufacturer, these solutions guarantee maximum release of BMP-2 and collagen as well as a decontamination of the root. When all the components were inserted and the cover of the machine was closed, the device was started using the general switch button. Demineralized dentin graft was ready in 25 minutes to be placed in the patient's mouth (TT TOOTH TRANSFORMER SRL, Via Washington, 59 - Milan, Italy).

In all cases, the graft was covered by a resorbable porcine pericardium membrane (BEGO Implant Systems GmbH \& Co. KG, Wilhelm-Herbst-Straße, Bremen, Germany) (Fig. 3). An immediate post-operative radiological check was performed (Fig. 4). Each patient underwent clinical examination after 10 and 30 days (Fig. 5) and (Fig. 6) in order to evaluate the healing process.

CBCT scans were performed before grafting procedures and after 6 months of healing (Fig. 7) in order to evaluate the quality and quantity of the newly formed bone that filled the defect. A clinical examination was performed during the reentry surgery after 6 months (Fig. 8) for implant insertion procedures (Fig. 9). Implants follow-up included a radiological examinations after 4 months (Fig. 10), at final crown delivery and every 6 months.

A total of 19 titanium dental implants were inserted during the surgical re-entry (6 months). The mean follow up period was 12 months.

\section{RESULTS}

In all cases, after 6 months of healing, the defects were completely filled by newly formed bone. All cases showed complete bone filling by clinical and radiographs observation. Surgical data and radiological measurements for each patient are summarized in Table $\mathbf{1}$. The newly formed tissue, observed during the surgical re-entry, had a compactness similar to the medium-density bone. The presence of graft particles or grains in sub mucous connective tissues was not recorded. No graft particles or grains were visible in the regenerated bone structure that appeared homogeneous and uniform. A D2-D3 bone density was detected during implant drilling procedures. All inserted implants reached high values of primary stability. In all cases, after 18 of 19 implants were inserted, complete osseointegration after proper healing period was achieved. 1 implant failed, and non osseointegration was detected during the second implant stage surgery. After the follow-up period of 12 months, hard and soft tissues were stable. The healing of soft tissues after grafting procedures was particularly free of complications. Even in cases where the surgical wound had not been closed by first intention, complete defect coverage was observed within 10-15 days without complications or painful symptoms.

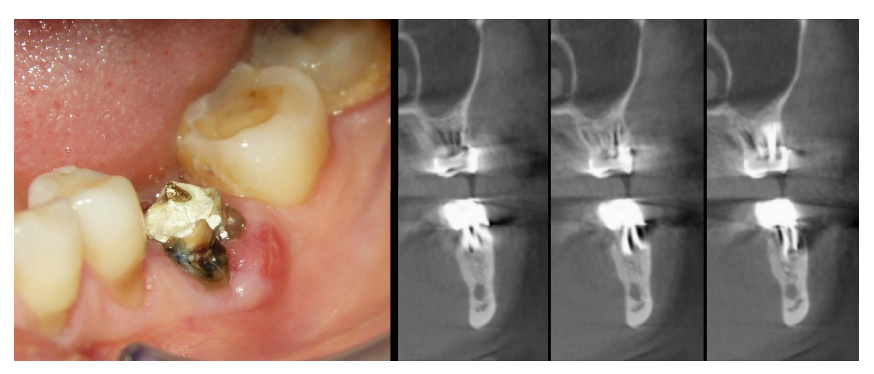

Fig. (1). Hopeless first lower left molar (left side). The cone bean scans clearly showed the loss of vestibular cortex due to radicular fracture (right side).

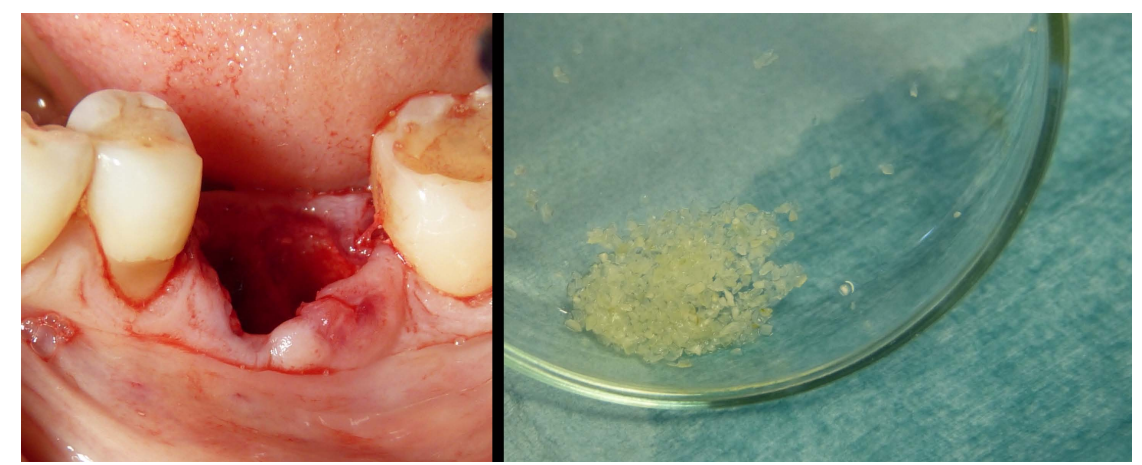

Fig. (2). Atraumatic extraction of first left lower molar (left side). Any filling materials was removed using diamond and steel burs. The tooth was cleaned from residual calculus using piezoelectric instruments. Finally, it was cut in small pieces to facilitate the milling process. Tooth pieces were inserted in the machine and the device was started using the general switch button. Demineralized dentin graft was ready in $30-45$ minutes to be placed in the patient's mouth (right side). The particles size ranged between 0,4 and 0,8 $\mathrm{mm}$. 


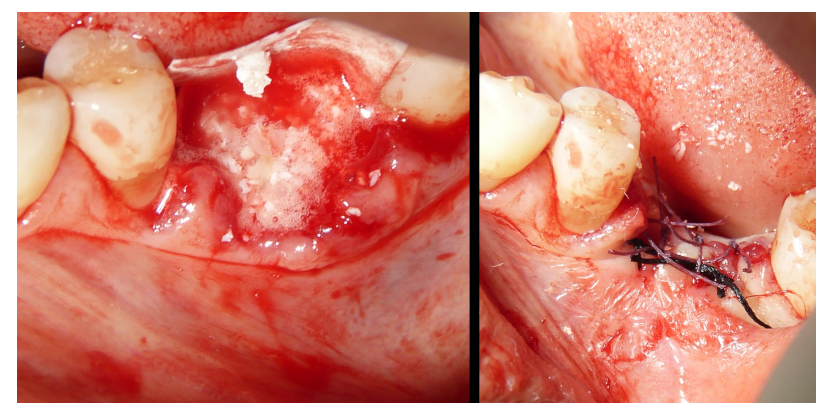

Fig. (3). Post extractive socket grafting procedures using autologous demineralized dentin. An absorbable collagen membrane was used to protect the graft (left side). First intention wound closure (right side).

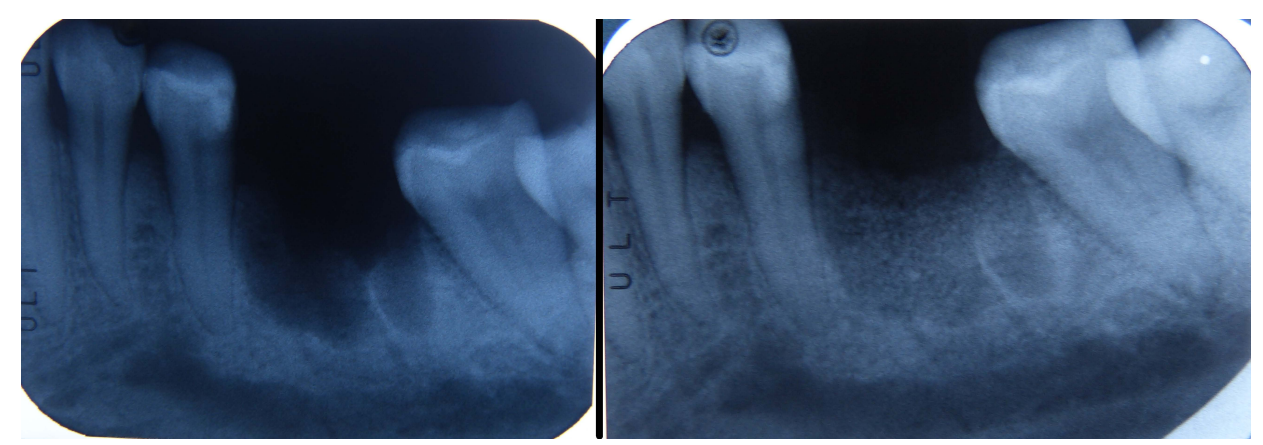

Fig. (4). Post extractive radiograph prior grafting procedures (left side). Radiograph after autologous dentin graft (right side): the complete filling is evident.

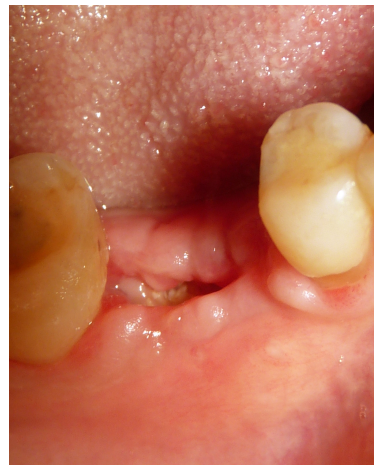

Fig. (5). Soft tissues healing after 10 days. No clinical signs of inflammation or infections are detected.

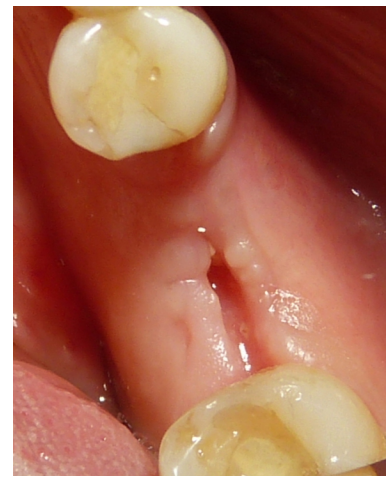

Fig. (6). Soft tissues aspect after 1 months. The wound showed an almost completely healing.

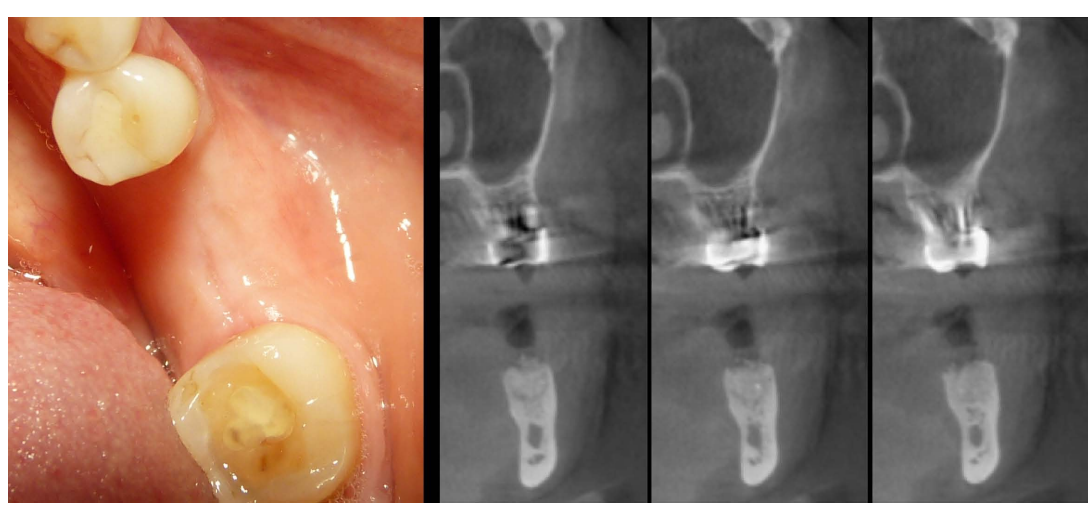

Fig. (7). Soft tissues healing after 6 months (left side). The cone bean scans showed a good integration between native bone and the autologous dentin graft. No signs of inflammations were present and the vestibular cortex was regenerated (right side). 


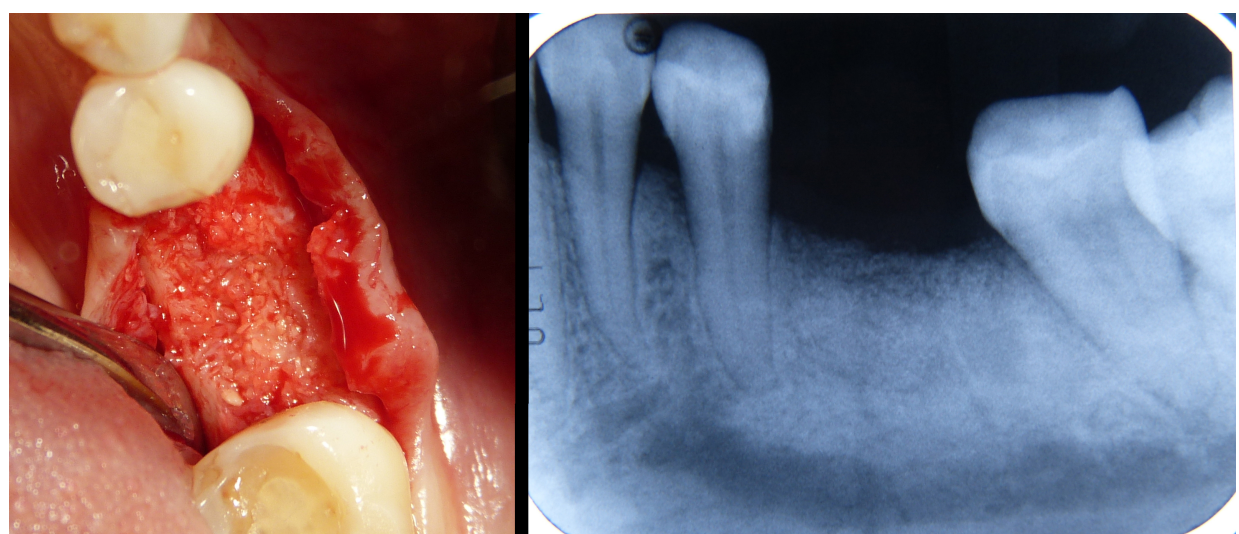

Fig. (8). Clinical aspect of the regenerated hard tissue (left side). A complete graft integration without any presence of inflammatory of connective tissue was evident. The radiograph (right side) showed no radio-opacity difference between the regenerated tissue and the surrounding bone.

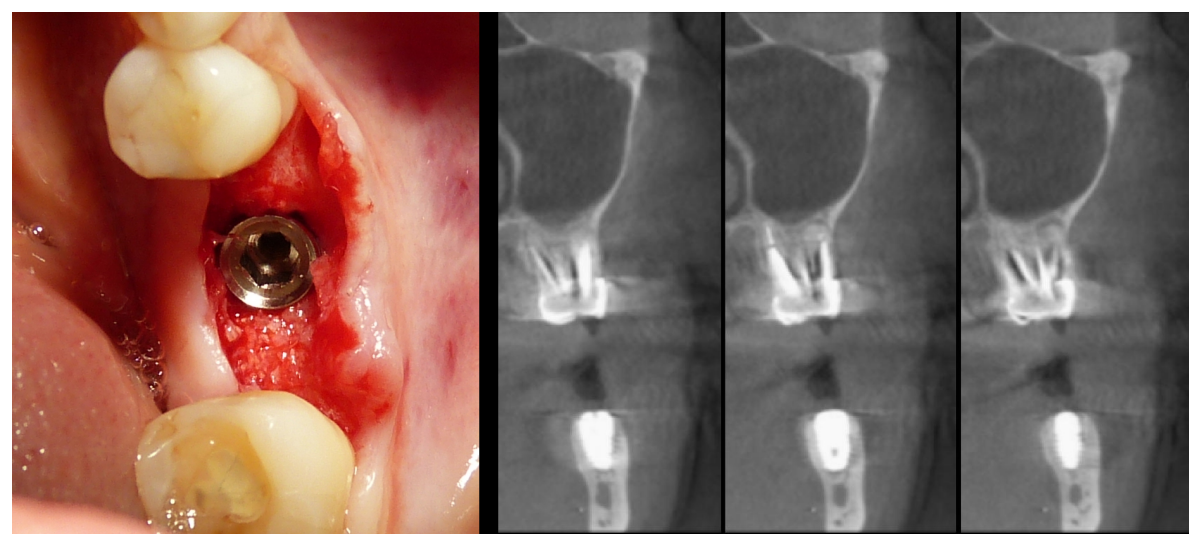

Fig. (9). Standard implant insertion procedures (left side). Cone bean scans confirmed the good implant tridimensional position (right side).

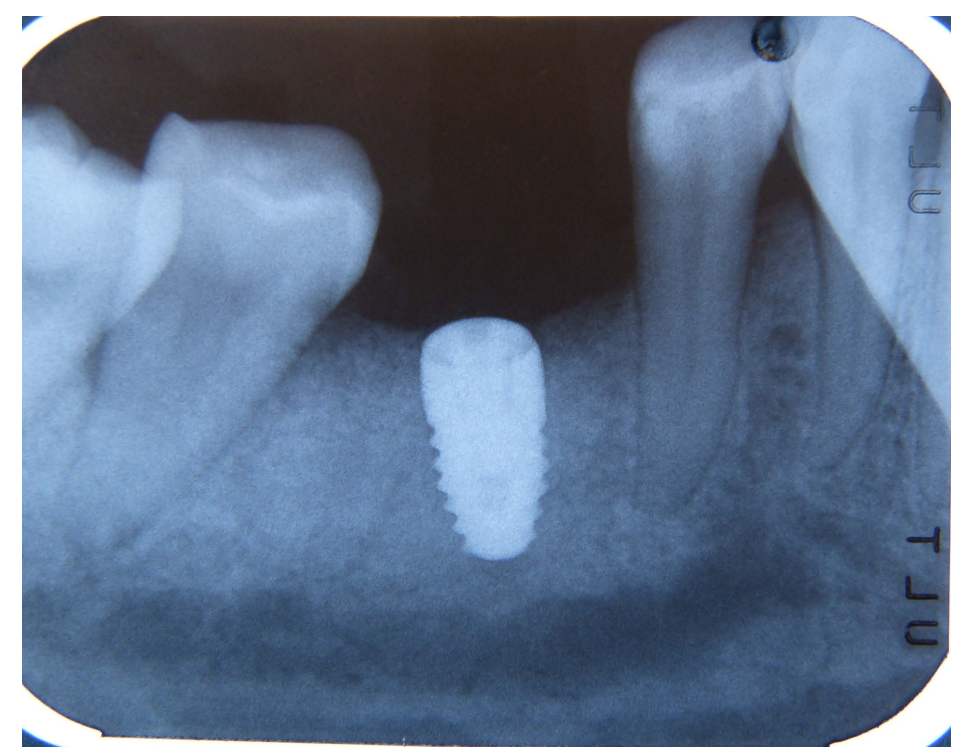

Fig. (10). Implant follow up. Radiograph 4 months after implant insertion. No signs of bone resorption were detected. 
Table 1. Surgical data of each patient treated using autologous tooth graft.

\begin{tabular}{|c|c|c|c|c|c|}
\hline $\begin{array}{l}\text { Patient } \\
\text { no. }\end{array}$ & Description & Notes & Tooth Used & $\begin{array}{l}\text { Initial Defect } \\
\text { (CBCT prior } \\
\text { grafting } \\
\text { procedures) } \\
\end{array}$ & $\begin{array}{l}\text { Defect Filling } \\
\text { (CBCT after } 6 \\
\text { monts) }\end{array}$ \\
\hline 1 & $\begin{array}{c}\text { Post extraction socket preservation. } 100 \% \text { autologous } \\
\text { tooth graft Resorbable collagen membrane } \\
\text { (pericardium). }\end{array}$ & $\begin{array}{c}\text { Insertion torque } \\
35 \mathrm{~N}\end{array}$ & $\begin{array}{l}\text { First lower left } \\
\text { molar }\end{array}$ & $\begin{array}{c}\text { Mesio - Distal: } 9.69 \\
\text { mm } \\
\text { Bucco - Lingual: } \\
7.04 \mathrm{~mm} \\
\text { Height: } 5.40 \mathrm{~mm} \\
\text { (Loss of lingual } \\
\text { cortex) }\end{array}$ & $\begin{array}{c}\text { Mesio - Distal: } 9.08 \\
\text { mm } \\
\text { Bucco - Lingual: } 9.80 \\
\text { Height: } 4.20 \mathrm{~mm}\end{array}$ \\
\hline 2 & $\begin{array}{c}\begin{array}{c}\text { Post extraction socket preservation. } 100 \% \text { autologous } \\
\text { tooth graft. Resorbable collagen membrane } \\
\text { (pericardium). }\end{array} \\
\end{array}$ & - & $\begin{array}{c}\text { Second lower } \\
\text { second premolar }\end{array}$ & $\begin{array}{c}\text { Mesio - Distal: } 8.94 \\
\text { mm } \\
\text { Height: } 7.23 \mathrm{~mm}\end{array}$ & $\begin{array}{l}\text { Mesio - Distal: } 8.94 \\
\text { mm } \\
\text { Height: } 7.20 \mathrm{~mm}\end{array}$ \\
\hline 3 & $\begin{array}{c}\text { Vertical guided bone regeneration. One implant was } \\
\text { placed in a contiguous zone. Resorbable collagen } \\
\text { membrane (pericardium). }\end{array}$ & - & $\begin{array}{c}\text { Third upper right } \\
\text { molar }\end{array}$ & $\begin{array}{l}\text { Mesio - Distal: } \\
\quad 11.55 \mathrm{~mm} \\
\text { Height: } 10.05 \mathrm{~mm}\end{array}$ & $\begin{array}{l}\text { Mesio - Distal: } 11.55 \\
\text { mm } \\
\text { Height: } 10 \mathrm{~mm}\end{array}$ \\
\hline 4 & $\begin{array}{c}\text { Post extraction socket preservation. } 100 \% \text { autologous } \\
\text { tooth graft. Resorbable collagen membrane } \\
\text { (pericardium). }\end{array}$ & $\begin{array}{l}\text { Loss of palatal } \\
\text { cortex }\end{array}$ & $\begin{array}{l}\text { First right upper } \\
\text { central incisor }\end{array}$ & $\begin{array}{c}\text { Mesio - Distal: } \\
11.30 \mathrm{~mm} \\
\text { Bucco - Lingual: } \\
10.37 \mathrm{~mm} \\
\text { Height: } 10.53 \mathrm{~mm}\end{array}$ & \begin{tabular}{|c} 
Mesio - Distal: 11.30 \\
mm \\
Bucco - Lingual: \\
$12.22 \mathrm{~mm}$ \\
Height: $10.56 \mathrm{~mm}$
\end{tabular} \\
\hline 5 & $\begin{array}{c}\text { Post extraction socket preservation. } 100 \% \text { autologous } \\
\text { tooth graft. Resorbable collagen membrane } \\
\text { (pericardium). }\end{array}$ & Implant failure & $\begin{array}{l}\text { First left upper } \\
\text { central incisor }\end{array}$ & $\begin{array}{c}\text { Mesio - Distal: } \\
13.18 \mathrm{~mm} \\
\text { Bucco - Lingual: } \\
14.47 \mathrm{~mm} \\
\text { Height: } 7.79 \mathrm{~mm}\end{array}$ & $\begin{array}{c}\text { Mesio - Distal: } 13.18 \\
\text { mm } \\
\text { Bucco -Lingual: } 14.50 \\
\text { Height: } 7.80 \mathrm{~mm}\end{array}$ \\
\hline 6 & $\begin{array}{c}\text { Post extraction socket preservation. } 100 \% \text { autologous } \\
\text { tooth graft. Resorbable collagen membrane } \\
\text { (pericardium). }\end{array}$ & - & $\begin{array}{l}\text { First upper left } \\
\text { premolar }\end{array}$ & $\begin{array}{c}\text { Mesio - Distal: } \\
11.30 \mathrm{~mm} \\
\text { Bucco - Lingual: } \\
9.27 \mathrm{~mm} \\
\text { Height: } 8.23 \mathrm{~mm}\end{array}$ & $\begin{array}{c}\text { Mesio - Distal: } 11.30 \\
\text { mm } \\
\text { Bucco - Lingual: } 8.89 \\
\text { mm } \\
\text { Height: } 8 \mathrm{~mm}\end{array}$ \\
\hline 7 & $\begin{array}{c}\begin{array}{c}\text { Vertical guided bone regeneration. } 100 \% \text { autologous } \\
\text { tooth graft. Resorbable collagen membrane } \\
\text { (pericardium). }\end{array} \\
\end{array}$ & $\begin{array}{l}\text { Loss of buccal } \\
\text { cortex }\end{array}$ & $\begin{array}{l}\text { First and second } \\
\text { lower left premolar }\end{array}$ & $\begin{array}{c}\text { Bucco - Lingual: } 7 \\
\text { mm } \\
\text { Height: } 8 \mathrm{~mm} \\
\end{array}$ & $\begin{array}{l}\text { Bucco - Lingual: } \\
10.03 \mathrm{~mm} \\
\text { Height: } 8.2 \mathrm{~mm}\end{array}$ \\
\hline 8 & $\begin{array}{c}\text { Post extraction socket preservation. } 100 \% \text { autologous } \\
\text { tooth graft. Resorbable collagen membrane } \\
\text { (pericardium). }\end{array}$ & $\begin{array}{l}\text { Presense of } \\
\text { apical cyst }\end{array}$ & $\begin{array}{l}\text { Second upper left } \\
\text { molar }\end{array}$ & $\begin{array}{c}\text { Mesio - Distal: } 8.52 \\
\text { mm } \\
\text { Bucco - Lingual: } \\
10.72 \mathrm{~mm} \\
\text { Height: } 11.7 \mathrm{~mm} \\
\end{array}$ & $\begin{array}{l}\text { Mesio - Distal: } 9 \mathrm{~mm} \\
\text { Bucco - Lingual: } \\
10.66 \mathrm{~mm} \\
\text { Height: } 10.95 \mathrm{~mm}\end{array}$ \\
\hline 9 & $\begin{array}{c}\text { Post extraction socket preservation. } 100 \% \text { autologous } \\
\text { tooth graft. Resorbable collagen membrane } \\
\text { (pericardium). }\end{array}$ & $\begin{array}{l}\text { Loss of lingual } \\
\text { cortex }\end{array}$ & $\begin{array}{l}\text { Central lower } \\
\text { incisors }\end{array}$ & $\begin{array}{c}\text { Mesio - Distal: } \\
\text { 12.04 mm } \\
\text { Bucco - Lingual: } 7 \\
\text { mm } \\
\text { Height: } 10.91 \mathrm{~mm} \\
\end{array}$ & $\begin{array}{c}\text { Mesio - Distal: } 12 \mathrm{~mm} \\
\text { Bucco - Lingual: } 6 \\
\text { mm } \\
\text { Height: } 10.34 \mathrm{~mm}\end{array}$ \\
\hline 10 & $\begin{array}{c}\text { Post extraction socket preservation. } 100 \% \text { autologous } \\
\text { tooth graft. Resorbable collagen membrane } \\
\text { (pericardium). }\end{array}$ & \begin{tabular}{|c|} 
Presence of \\
apical cyst with \\
lingual cortex \\
loss.
\end{tabular} & \begin{tabular}{|c|} 
Deciduos \\
teeth preserved in a \\
plastic box from 15 \\
years.
\end{tabular} & $\begin{array}{c}\text { Mesio - Distal: } 8.57 \\
\text { mm } \\
\text { Bucco - Lingual: } \\
4.72 \mathrm{~mm} \\
\text { Height: } 10.10 \mathrm{~mm} \\
\end{array}$ & $\begin{array}{c}\text { Mesio - Distal: } 8.58 \\
\text { mm } \\
\text { Bucco - Lingual: } 4.80 \\
\text { mm } \\
\text { Height: } 10.50 \mathrm{~mm}\end{array}$ \\
\hline 11 & $\begin{array}{c}\text { Post extraction socket preservation. } 100 \% \text { autologous } \\
\text { tooth graft. Resorbable collagen membrane } \\
\text { (pericardium). }\end{array}$ & - & $\begin{array}{l}\text { Second upper left } \\
\text { molar }\end{array}$ & $\begin{array}{c}\text { Mesio - Distal: } \\
13.18 \mathrm{~mm} \\
\text { Bucco - Lingual: } \\
14.47 \mathrm{~mm} \\
\text { Height: } 8 \mathrm{~mm} \\
\end{array}$ & $\begin{array}{c}\text { Mesio - Distal: } 13 \mathrm{~mm} \\
\text { Bucco - Lingual: } \\
14.50 \mathrm{~mm} \\
\text { Height: } 8 \mathrm{~mm}\end{array}$ \\
\hline 12 & $\begin{array}{c}\begin{array}{c}\text { Sinus lift (lateral window technique) using tooth as } \\
\text { graft material. Readsorbable membrane to protect the } \\
\text { sinus membrane. }\end{array} \\
\end{array}$ & $\begin{array}{c}\text { Implant insertion } \\
\text { after } 6 \text { months }\end{array}$ & $\begin{array}{l}\text { Three wisdom teeth } \\
\text { preserved in plastic } \\
\text { box for twenty years }\end{array}$ & - & $\begin{array}{l}\text { Volume maintained, } \\
\text { uniform radiopacity }\end{array}$ \\
\hline 13 & $\begin{array}{c}\begin{array}{c}\text { Sinus lift (lateral window technique) using tooth as } \\
\text { graft material. Readsorbable membrane to protect the } \\
\text { sinus membrane. }\end{array} \\
\end{array}$ & $\begin{array}{c}\text { Immediate } \\
\text { implant insertion }\end{array}$ & $\begin{array}{l}\text { Upper right first } \\
\text { molar }\end{array}$ & - & $\begin{array}{l}\text { Volume maintained, } \\
\text { uniform radiopacity }\end{array}$ \\
\hline 14 & $\begin{array}{c}\text { Sinus lift (lateral window technique) using tooth as } \\
\text { graft material. Readsorbable membrane to protect the } \\
\text { sinus membrane. }\end{array}$ & $\begin{array}{c}\text { Immediate } \\
\text { implant insertion }\end{array}$ & $\begin{array}{l}\text { First and second } \\
\text { right premolars }\end{array}$ & - & $\begin{array}{l}\text { Volume maintained, } \\
\text { uniform radiopacity }\end{array}$ \\
\hline
\end{tabular}


(Table 1) contd.....

\begin{tabular}{|c|c|c|c|c|c|}
\hline $\begin{array}{c}\text { Patient } \\
\text { no. }\end{array}$ & Description & Notes & Tooth Used & $\begin{array}{c}\text { Initial Defect } \\
\text { (CBCT prior } \\
\text { grafting } \\
\text { procedures) }\end{array}$ & $\begin{array}{c}\text { Defect Filling } \\
\text { (CBCT after 6 } \\
\text { monts) }\end{array}$ \\
\hline 15 & $\begin{array}{c}\text { Sinus lift (lateral window technique) using tooth as } \\
\text { graft material. Readsorbable membrane to protect the } \\
\text { sinus membrane. }\end{array}$ & $\begin{array}{c}\text { Presence of } \\
\text { apical cyst }\end{array}$ & $\begin{array}{c}\text { First upper right } \\
\text { premolar and first } \\
\text { upper right molar }\end{array}$ & $\begin{array}{c}\text { Volume maintained, } \\
\text { uniform radiopacity }\end{array}$ \\
\hline
\end{tabular}

\section{DISCUSSION}

The ideal grafting material should provide scaffolds for bone regeneration (osteoconduction) and, at the same time, should promote the recruitment of bone forming cells (such as preosteoblasts) and induce new bone formation (osteoinduction) [19].

Autologous bone graft has been considered the gold standard in bone regeneration procedures but donor site morbidity, pain, and prolonged hospitalization (in case of extra oral donor sites) have prompted the search for bone graft substitutes [20]. Too fast reabsorption rate has also been reported for autologous bone graft.

Xenograft materials have been used for many years with success [21], in various fields of oral bone regeneration procedures, often in association with dental implants. Many studies [22, 23] demonstrated that these regeneration materials are space maintaining and efficient scaffolds [24] for osteogenetic cells migration but they did not offer any osteoinduction properties. The chemical or physical processes to eliminate any organic residuals, which all xenograft materials are used, destroyed all proteins that are fundamental in bone regeneration promotion. Other authors reported [25] that allografts show faster turnover and a quicker decrease in biological action than xenografts.

On the other hand, many studies demonstrated that demineralized tooth graft is able to maintain the autogenous growth factors (such as osteopontin, dentin sialoprotein and BMP) and, for this reason, could induce bone formation (osteoinduction).

In fact, dentoalveolar ankylosis with osseous replacement is often seen after replantation of avulsed teeth and this exact mechanism could explain the osteoinductive properties of demineralized dentin matrixare that acts as a slow-releasing carrier of Bone Morphogenic Proteins (BMP) [26] and it was observed that tooth graft material produced a similar amount of new bone compared to autogenous bone graft (iliac crest) [27].

Growth factors, such as Insulin-like Growth Factor (IGF), Bone Morphogenetic Protein-2 (BMP-2) and Transforming Growth Factor (TGF- $\beta$ ) are preserved over the time; in fact, they were extracted from archaeological compact human bone and tooth dentin dating from the late pre-ceramic pottery Neolithic and the early Middle Ages [28].

Previous authors [29] used autogenous demineralized dentin matrix on dental socket wound healing process in humans and they reported that dentin matrix gradually disappeared from the dental socket during the course of the repair process, suggesting its resorption during the bone remodeling process.

In the 2014 [30] tooth bone graft was considered as a good alternative to a heterologous bone graft when extraction is necessary prior to the surgery and two years later, in 2016, a case series was published showing successful subsistence of the cortico-cancellous bone volume using with an average follow-up of 5 years .

A recent literature review [31] identified 108 studies about autogenous teeth used for bone grafting and selected 6 among them. The authors reported an implant survival rate of $97.7 \%$ and found that the dehiscence of the wound was a frequent complication. Another animal study [32] showed accelerated bone healing in defects treated by autogenous demineralized dentin matrix and PTFE membrane in respect with PTFE membrane alone.

Clinical studies [33] on Guided Bone Regeneration (GBR), socket preservation, and ridge augmentation showed new bone formation and the crestal bone resorption during the follow-up period was very low.

Pang et al. [34], compared clinical and histological performances of autogenous demineralized dentin matrix from extracted tooth versus anorganic bovine bone in 33 cases of socket preservation after tooth extraction. They found new bone formation and vertical bone increase in both groups without any significant difference.

The results showed by the present study confirmed those showed by Kim YK et al., that found favorable bony healing by osteoconduction in a GBR case series study with 15 patients and a 31-month follow-up period [35].

This paper shows clinical and radiological observations of a limited number of cases in which tooth graft was used for bone regeneration procedures. Standardized and controlled studies with large sample size are needed, in the next future, to validate the findings of the present case series analysis.

\section{CONCLUSION}

This innovative device allowed to process and use, as bone graft, any patient's tooth in a very short time. All decontamination, disinfection and demineralization processes are totally electronically managed by the machine itself without any possibility of human error or injury.

Future studies with long follow up period are needed in order to better evaluate the potential of demineralized dentin autografts.

\section{ETHICS APPROVAL AND CONSENT TO PART- ICIPATE}

Not applicable.

\section{HUMAN AND ANIMAL RIGHTS}

No animals/humans were used for studies that are the basis 
of this study.

\section{CONSENT FOR PUBLICATION}

An informed and written consent to the surgical treatment was obtained from each patient.

\section{FUNDING}

None.

\section{CONFLICT OF INTEREST}

The authors declare no conflict of interest, financial or otherwise.

\section{ACKNOWLEDGEMENTS}

Marco Berardini and Paolo Trisi claim to have no financial interest, either directly or indirectly, in the products or information listed in the article. Elio Minetti acts as consultant for TT TOOTH TRANSFORMER SRL (Via Washington, 59 Milan, Italy).

\section{REFERENCES}

[1] Boyne PJ. Experimental evaluation of the osteogenic potential of bone graft materials. Annu Meet Am Inst Oral Biol 1969; 13-21. [PMID: 4902452]

[2] Mellonig JT, Bowers GM, Cotton WR. Comparison of bone graft materials. Part II. New bone formation with autografts and allografts: A histological evaluation. J Periodontol 1981; 52(6): 297-302. [http://dx.doi.org/10.1902/jop.1981.52.6.297] [PMID: 7021792]

[3] Yeomans JD, Urist MR. Bone induction by decalcified dentine implanted into oral, osseous and muscle tissues. Arch Oral Biol 1967; 12(8): 999-1008

[http://dx.doi.org/10.1016/0003-9969(67)90095-7] [PMID: 42 26721]

[4] Bang G, Urist MR. Bone induction in excavation chambers in matrix of decalcified dentin. Arch Surg 1967; 94(6): 781-9.

[http://dx.doi.org/10.1001/archsurg.1967.01330120035008] [PMID: 4226076]

[5] Kawai T, Urist MR. Bovine tooth-derived bone morphogenetic protein. J Dent Res 1989; 68(6): 1069-74.

[http://dx.doi.org/10.1177/00220345890680060301] [PMID: 2808865]

[6] Bessho K, Tanaka N, Matsumoto J, Tagawa T, Murata M. Human dentin-matrix-derived bone morphogenetic protein. J Dent Res 1991; 70(3): 171-5.

[http://dx.doi.org/10.1177/00220345910700030301] [PMID: 1999554]

[7] Kim KW. Bone induction by demineralized dentin matrix in nude mouse muscles. Maxillofac Plast Reconstr Surg 2014; 36(2): 50-6. [http://dx.doi.org/10.14402/jkamprs.2014.36.2.50] [PMID: 27 489810]

[8] Minamizato T, Koga T, Nakatani Y, et al. Clinical application of autogenous partially demineralized dentin matrix prepared immediately after extraction for alveolar bone regeneration in implant dentistry: A pilot study. Int J Oral Maxillofac Surg 2018; 47(1): 125-32.

[http://dx.doi.org/10.1016/j.ijom.2017.02.1279] [PMID: 2880 2762]

[9] Kim SY, Kim YK, Park YH, et al. Evaluation of the healing potential of demineralized dentin matrix fixed with recombinant human bone morphogenetic protein-2 in bone grafts. Materials (Basel) 2017; 10(9): E1049.

[http://dx.doi.org/10.3390/ma10091049] [PMID: 28880245]

[10] Nakashima M. Bone morphogenetic proteins in dentin regeneration for potential use in endodontic therapy. Cytokine Growth Factor Rev 2005; 16(3): 369-76.

[http://dx.doi.org/10.1016/j.cytogfr.2005.02.011] [PMID: 1587 8301]

[11] Kim YK, Lee J. Tooth derived bone graft material. Koreen Ass Oral Max Surg 2013; 39: 103-11.

[http://dx.doi.org/10.5125/jkaoms.2013.39.3.103]

[12] Blum B. Measurement of bone morphogenetic proteins and other growth factors in demineralized bone matrix. Orthopedics 2004; $27(1$ Suppl p. s 1): 61-5.

[13] Um IW, Kim YK, Mitsugi M. Demineralized dentin matrix scaffolds for alveolar bone engineering. J Indian Prosthodont Soc 2017; 17(2):
$120-7$

[http://dx.doi.org/10.4103/jips.jips 62 17] [PMID: 28584412]

[14] Reddi AH, Huggins CB. Influence of geometry of transplanted tooth and bone on transformation of fibroblasts. Proc Soc Exp Biol Med 1973 ; 143(3): 634-7.

[http://dx.doi.org/10.3181/00379727-143-37381] [PMID: 4578 252]

[15] Koga T, Minamizato T, Kawai Y, et al. Bone regeneration using dentin matrix depends on the degree of demineralization and particle size. PLoS One 2016; 11(1): e0147235.

[http://dx.doi.org/10.1371/journal.pone.0147235] [PMID: 2679 5024]

[16] Binderman I, Hallel G, Nardy C, Yaffe A, Sapoznikof L. A nove procedure to process extracted teeth for immediate grafting autogenous dentin. Interdisciplin Med Dental Sci 2014; 2: 154-8.

[17] Bono N, Tarsini P, Candiani G. BMP-2 and type I collagen preservation in human deciduous teeth after demineralization. J Appl Biomater Funct Mater 2018; 1-8.

[http://dx.doi.org/2280800018784230] [PMID: 30045659]

[18] Bono N, Tarsini P, Candiani G. Demineralized dentin and enamel matrices as suitable substrates for bone regeneration. J Appl Biomater Funct Mater 2017; 15(3): e236-43.

[http://dx.doi.org/10.5301/jabfm.5000373] [PMID: 28731486]

[19] Nampo T, Watahiki J, Enomoto A. A new method for alveolar bone repair using extracted teeth for the graft material. J Periodontol 2010; 81: 1264-72.

[20] Liang F, Leland H, Jedrzejewski B, et al. Alternatives to autologous bone graft in alveolar cleft reconstruction: The state of alveolar tissue engineering. J Craniofac Surg 2018; 29(3): 584-93.

[21] Guarnieri R, Testarelli L, Stefanelli L, et al. Bone healing in extraction sockets covered with collagen membrane alone or associated with porcine-derived bone graft: A comparative histological and histomorphometric analysis. J Oral Maxillofac Res 2017; 8(4): e4. [http://dx.doi.org/10.5037/jomr.2017.8404] [PMID: 294352 06]

[22] Ortiz-Vigón A, Suarez I, Martínez-Villa S, Sanz-Martín I, Bollain J, Sanz M. Safety and performance of a novel collagenated xenogeneic bone block for lateral alveolar crest augmentation for staged implant placement. Clin Oral Implants Res 2018; 29(1): 36-45. [http://dx.doi.org/10.1111/clr.13036] [PMID: 28710793]

[23] Mordenfeld A, Aludden H, Starch-Jensen T. Lateral ridge augmentation with two different ratios of deproteinized bovine bone and autogenous bone: A 2-year follow-up of a randomized and controlled trial. Clin Implant Dent Relat Res 2017; 19(5): 884-94. [http://dx.doi.org/10.1111/cid.12512] [PMID: 28656713]

[24] Troeltzsch M, Troeltzsch M, Kauffmann P, et al. Clinical efficacy of grafting materials in alveolar ridge augmentation: A systematic review. J Craniomaxillofac Surg 2016; 44(10): 1618-29. [http://dx.doi.org/10.1016/j.jcms.2016.07.028] [PMID: 2762 2971]

[25] Galindo-Moreno P, de Buitrago JG, Padial-Molina M, FernándezBarbero JE, Ata-Ali J, O Valle F. Histopathological comparison of healing after maxillary sinus augmentation using xenograft mixed with autogenous bone versus allograft mixed with autogenous bone. Clin Oral Implants Res 2018; 29(2): 192-201.

[http://dx.doi.org/10.1111/clr.13098] [PMID: 29071736]

[26] Al-Asfour A, Farzad P, Andersson L, Joseph B, Dahlin C. Host tissue reactions of non-demineralized autogenic and xenogenic dentin blocks implanted in a non-osteogenic environment. An experimental study in rabbits. Dent Traumatol 2014; 30(3): 198-203.

[http://dx.doi.org/10.1111/edt.12066] [PMID: 23991864]

[27] Nampo T, Watahiki J, Enomoto A, et al. A new method for alveola bone repair using extracted teeth for the graft material. J Periodontol 2010; 81(9): 1264-72.

[http://dx.doi.org/10.1902/jop.2010.100016] [PMID: 204768 87]

[28] Schmidt-Schultz TH, Schultz M. Intact growth factors are conserved in the extracellular matrix of ancient human bone and teeth: A storehouse for the study of human evolution in health and disease. Biol Chem 2005; 386(8): 767-76. [http://dx.doi.org/10.1515/BC.2005.090] [PMID: 16201872]

[29] Gomes MF, Abreu PP, Morosolli AR, Araújo MM, Goulart Md. Densitometric analysis of the autogenous demineralized dentin matrix on the dental socket wound healing process in humans. Braz Oral Res 2006; 20(4): 324-30.

[http://dx.doi.org/10.1590/S1806-83242006000400008] [PMID: 1724 2793]

[30] Kim YK, Lee J, Yun JY, Yun PY, Um IW. Comparison of autogenous tooth bone graft and synthetic bone graft materials used for bone resorption around implants after crestal approach sinus lifting: A retrospective study. J Periodontal Implant Sci 2014; 44(5): 216-21. [http://dx.doi.org/10.5051/jpis.2014.44.5.216] [PMID: 25368 809] 
[31] Gual-Vaqués P, Polis-Yanes C, Estrugo-Devesa A, Ayuso-Montero R, Mari-Roig A, López-López J. Autogenous teeth used for bone grafting: A systematic review. Med Oral Patol Oral Cir Bucal 2018; 23(1): e112-9.

[PMID: 29274156]

[32] Gomes MF, dos Anjos MJ, Nogueira TdeO, Catanzaro Guimarães SA. Autogenous demineralized dentin matrix for tissue engineering applications: Radiographic and histomor- phometric studies. Int J Oral Maxillofac Implants 2002; 17(4): 488-97.

[PMID: 12182291]

[33] Park SM, Um IW, Kim YK, Kim KW. Clinical application of autotooth bone graft material. J Korean Assoc Oral Maxillofac Surg 2012;
38: $2-8$.

[http://dx.doi.org/10.5125/jkaoms.2012.38.1.2]

[34] Pang KM, Um IW, Kim YK, Woo JM, Kim SM, Lee JH. Autogenous demineralized dentin matrix from extracted tooth for the augmentation of alveolar bone defect: A prospective randomized clinical trial in comparison with anorganic bovine bone. Clin Oral Implants Res 2017; 28(7): 809-15.

[http://dx.doi.org/10.1111/clr.12885] [PMID: 27279547]

[35] Kim YK, Kim SG, Bae JH, Um IW, Oh JS, Jeong KI. Guided bone regeneration using autogenous tooth bone graft in implant therapy: Case series. Implant Dent 2014; 23(2): 138-43.

[http://dx.doi.org/10.1097/ID.0000000000000046] [PMID: 24637527]

\section{C) 2019 Minetti et al.}

This is an open access article distributed under the terms of the Creative Commons Attribution 4.0 International Public License (CC-BY 4.0), a copy of which is available at: https://creativecommons.org/licenses/by/4.0/legalcode. This license permits unrestricted use, distribution, and reproduction in any medium, provided the original author and source are credited. 